\title{
Closing nutrient loops through decentralized anaerobic digestion of organic residues in agricultural regions: A multi-dimensional sustainability assessment
}

Vaneeckhaute, Celine; Styles, David; Prade, Thomas; Adams, Paul; Thelin, Gunnar; Rodhe, Lena; d'Hertefeldt, Tina

\section{Resources, Conservation and Recycling}

Published: 01/09/2018

Peer reviewed version

Cyswllt i'r cyhoeddiad / Link to publication

Dyfyniad o'r fersiwn a gyhoeddwyd / Citation for published version (APA):

Vaneeckhaute, C., Styles, D., Prade, T., Adams, P., Thelin, G., Rodhe, L., \& d'Hertefeldt, T. (2018). Closing nutrient loops through decentralized anaerobic digestion of organic residues in agricultural regions: A multi-dimensional sustainability assessment. Resources, Conservation and Recycling, 136, 110.

\section{Hawliau Cyffredinol / General rights}

Copyright and moral rights for the publications made accessible in the public portal are retained by the authors and/or other copyright owners and it is a condition of accessing publications that users recognise and abide by the legal requirements associated with these rights.

- Users may download and print one copy of any publication from the public portal for the purpose of private study or research.

- You may not further distribute the material or use it for any profit-making activity or commercial gain

- You may freely distribute the URL identifying the publication in the public portal ?

Take down policy

If you believe that this document breaches copyright please contact us providing details, and we will remove access to the work immediately and investigate your claim. 
Closing nutrient loops through decentralized anaerobic digestion of organic residues in agricultural regions: A multi-dimensional sustainability assessment

Céline Vaneeckhaute ${ }^{\mathrm{a}, \mathrm{b}}$, David Styles ${ }^{\mathrm{c}}$, Thomas Prade ${ }^{\mathrm{d}}$, Paul Adams ${ }^{\mathrm{e}}$, Gunnar Thelin ${ }^{\mathrm{f}}$, Lena Rodhe ${ }^{\mathrm{g}}$, Tina D'Hertefeldt ${ }^{\mathrm{h}}$

${ }^{a}$ BioEngine, Chemical Engineering Department, Université Laval, 1065 avenue de la Médecine, Québec, QC, Canada, G1V0A6, celine.vaneeckhaute@gch.ulaval.ca

${ }^{\mathrm{b}}$ CentrEau, Centre de recherche sur l'eau, Université Laval, 1065 avenue de la Médecine,

10 Québec, QC, Canada, G1V 0A6, celine.vaneeckhaute@gch.ulaval.ca

11 'School of Environment, Natural Resources and Geography, Bangor University, Gwynedd, UK, $12 \quad$ LL57 2UW, d.styles@bangor.ac.uk

13 Department of Biosystems and Technology, Swedish University of Agricultural Sciences, 14 Alnarp, Sweden, SE-23053, thomas.prade@slu.se

15 e Department of Mechanical Engineering, Bath University, North East Somerset, UK, BA2 16 7AY, p.w.r.adams@bath.ac.uk

17 EEkobalans, Scheelevägen 22, Lund, Sweden, SE-22363, gunnar.thelin@ekobalans.se

18 gRISE Research Institutes of Sweden, Uppsala, Sweden, SE-75007, lena.rodhe@jti.se

19 hepartment of Biology, Lund University, Lund, Sweden, SE-22362, tina.dhertefeldt@biol.lu.se 
Decentralized anaerobic digestion (AD) of manure and organic residues is a possible strategy to improve carbon and nutrient cycling within agricultural regions, meanwhile generating renewable energy. To date, there has been limited adoption of decentralized AD technology in industrialized countries owing to low profitability for plant operators. There remains a need to demonstrate the wider sustainability of small-scale, decentralized AD in order to justify policy support for such a strategy. This study applies a multi-dimensional assessment of the environmental, economic and social sustainability of two scenarios of decentralized, farm-scale AD of pig slurry and organic residues in Southern Sweden. The environmental dimension was assessed by means of an expanded boundary life cycle assessment, in which trade-offs between fertilizer replacement, soil organic carbon accumulation, digestate/manure storage and application, transport and soil emissions were evaluated. The economic dimension was assessed through modelling of the net present value and internal rate of return. Finally, the social dimension was assessed by means of a stakeholder perception inquiry among key stakeholders in the field. It was concluded that the overall environmental balance of decentralized AD was favorable, while also the net present value could be positive. Fertilizer replacement, soil organic carbon and digestate storage effects were identified as important factors that should be accounted for in future life cycle assessments. A key issue for interviewed stakeholders was product quality assurance. Wider application of multi-dimensional sustainability assessment, capturing important nutrient cycling effects, could provide an evidence base for policy to support sustainable deployment of decentralized AD.

Keywords: anaerobic digestion; bio-based fertilizers; circular economy; resource recovery; sustainable farming; nutrient management.

\section{Introduction}

The European Union has committed itself to an average reduction of greenhouse gas (GHG) 
agriculture is projected to obtain a $17 \%$ reduction in GHG emissions by 2020 , partly due to decreasing use of fertilizers and increasing productivity (EuroStat, 2017). Indeed, the agricultural sector is responsible for more than $40 \%$ of anthropogenic methane $\left(\mathrm{CH}_{4}\right)$ emissions and more than $50 \%$ of nitrous oxide $\left(\mathrm{N}_{2} \mathrm{O}\right.$ ) emissions (EuroStat, 2017). Both $\mathrm{CH}_{4}$ and $\mathrm{N}_{2} \mathrm{O}$ are GHGs with global warming potentials that are, respectively, 25 and 298 times greater than that of carbon dioxide $\left(\mathrm{CO}_{2}\right)$ (EuroStat, 2017). The main sources of $\mathrm{CH}_{4}$ are enteric fermentation and manure management, while $\mathrm{N}_{2} \mathrm{O}$ is mainly derived from the turnover of nitrogen in fertilizers, manure and crop residues, and indirectly from the turnover of nitrogen lost to the environment via ammonia volatilization or nitrate leaching (EuroStat, 2017). Significant reductions in GHG emissions are therefore expected if $\mathrm{CH}_{4}$ and $\mathrm{N}_{2} \mathrm{O}$ emissions can be reduced via improved management practices in agriculture.

Decentralized anaerobic digestion (AD) in agriculture provides possibilities to reduce GHG emissions by producing a $\mathrm{CH}_{4}$-rich biogas from manure and crop residues. A decentralized biogas plant is a small digester located on a farm that treats substrates from the farm and local sources such as household food waste and waste from food processing plants. Such small biogas plants could fulfill a useful role in rural areas where cumulatively large amounts of organic wastes are often handled sub-optimally owing to costs of transporting them to large centralized AD facilities. The produced biogas can be transformed into electricity, heat or fuel for the farm, while the resulting digested waste, i.e. the digestate, can be returned to land as a valuable organic-mineral fertilizer, thereby reducing the use of chemical fertilizers (Vaneeckhaute et al., 2013a, 2014, 2016). As such, closed loop recycling management systems could be strengthened and emissions from conventional manure storage and application could potentially be reduced. The use of digestate can also contribute to carbon sequestration, since digestate organics are incorporated into the soil (Vaneeckhaute et al., 2013a, 2014). Anaerobic digestion can also create new sources of income for farmers, such as carbon credits.

Despite many opportunities for farm-scale biogas plant development in rural regions, the widespread adoption of decentralized biogas technology has yet to take off (ADAS and SAC, 2007). Currently less than one percent of the potential benefits from anaerobic digestion are being realized (EUBIA, 2017). Reasons for this include the non-supportive regulatory framework, the lack of economic incentives for potential investors, as well as the lack of knowledge and accurate quantitative studies on the potential benefits of decentralized digestion (EUBIA, 2017). There is a need for a scientifically robust evidence base for policy to support decentralized $\mathrm{AD}$, integrating the economic, social and environmental pillars of sustainability.

Life cycle assessment (LCA) is increasingly being applied to evaluate the environmental sustainability of AD (e.g., Chiew et al., 2015; Rehl and Müller, 2011; Vázquez-Rowe et al., 2015), but emphasis is usually placed on energy generation, while nutrient and soil organic carbon (SOC) effects are considered in less detail using crude assumptions, with some exceptions (e.g., Cong et al., 2017). Further, environmental effects of storage of manure or digestate, such as emissions and potential nutrient losses, can wholly or partly offset the benefits of nutrient recycling from these products. Storage of residues is, however, often not fully accounted for, for example, the EU Renewable Energy Directive 2009/28/EC neglects digestate storage, and many existing LCAs seem to overlook the importance of effective manure/digestate storage with respect to nutrient losses and GHG emissions (EC, 2009; JRC, 2014). Moreover, a holistic LCA study should be accompanied with an evaluation of the economic benefits/losses when changing farm management practices. Finally, even if environmental and economic benefits are clear, recycled fertilizer marketing will be highly influenced by the social perception in the agricultural region. Ideally, a more holistic and multi- 
dimensional sustainability assessment framework for the use of biofertilizers in agriculture should be applied in order to evaluate the real potential benefits of decentralized anaerobic digestion.

The aim of this study was to identify the environmental, economic and social sustainability of using digested waste (pig manure, food waste, slaughterhouse waste and grass silage, notably), hereafter called residue biofertilizers (RBFs), instead of raw animal manure and synthetic fertilizer in decentralized agricultural regions. To this end, a multi-dimensional sustainability assessment is performed for the case of Southern Sweden. A concept map of the research strategy is provided in Figure 1.

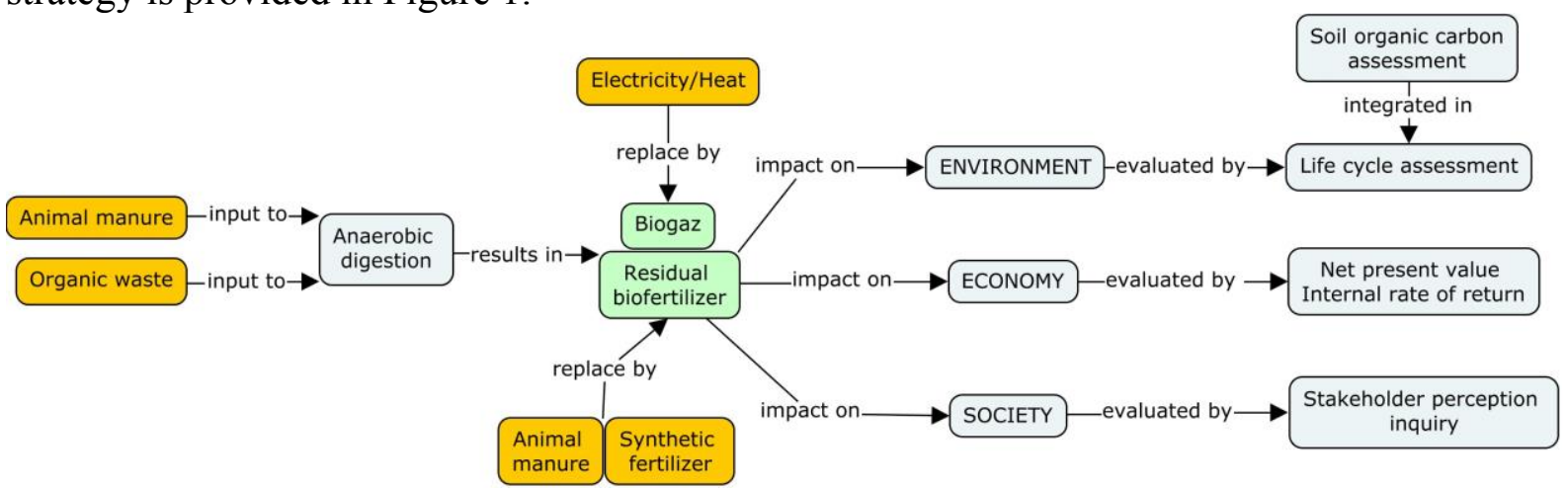

Figure 1: Concept map of the multi-dimensional sustainability assessment framework proposed in this study.

The environmental dimension was investigated through an LCA, accounting for trade-offs between digestate storage, fertilizer replacement and soil organic carbon effects, transport and soil emissions for using RBFs, as well as counterfactual effects of the avoided conventional manure and waste management. The economic dimension was assessed by means of a technoeconomic analysis of decentralized $\mathrm{AD}$ and digestate handling at the farm level, resulting in net present value (NPV) and internal rate of return (IRR) economic indicators. The social dimension was assessed by means of a stakeholder perception inquiry that investigates the acceptance of RBFs in agriculture among different key stakeholders in Southern Sweden. As such, this research will help identifying key bottlenecks in the widespread implementation of anaerobic digestion and digestate recycling in decentralized regions, and indicate opportunities, e.g., in terms of policy amendments and priority measures, to enable more effective usage of recycled nutrients.

\section{Methods}

\subsection{Environmental dimension}

\subsubsection{LCA framework for residue biofertilizers}

Table 1 lists the key processes and factors to consider when undertaking an LCA of RBFs. A first important issue is where to draw LCA boundaries, which will depend on the type of LCA to be applied (attributional or consequential), the question being asked and the prevailing fate of the residue investigated in the region of study used to define the baseline (Table 1). Fertilizer replacement value (FRV) is a key determining factor for the environmental balance of RBF (Vaneeckhaute et al., 2013a, 2014). Therefore, it is relevant to apply an expanded boundary, or consequential, LCA to fully evaluate the environmental balance of RBFs. Given the multiple nutrients delivered in RBFs, it is difficult to define a simple functional unit. Instead, results may 
be expressed for a reference flow, such as $1 \mathrm{Mg}$ dry matter (DM) of RBF, considering all relevant incurred and avoided effects. In Table 1, it is suggested that the following impact categories are particularly important to represent main elements of the environmental balance of RBF: i) global warming potential (GWP), ii) eutrophication potential (EP), iii) acidification potential (AP), and iv) fossil resource depletion potential (FRDP), as, e.g., in CML (2010). Other environmental impact categories such as human toxicity and freshwater eco-toxicity (CML, 2010) may be relevant for some RBFs, especially those containing heavy metals or other impurities, but are not investigated further in this study.

Field application of residues will give rise to emissions to air and water, most importantly $\mathrm{NH}_{3}$, $\mathrm{N}_{2} \mathrm{O}, \mathrm{NO}_{3}, \mathrm{PO}_{4}$, which can be estimated or modelled using various sources (e.g., IPCC, 2006; Johnes et al., 1996; Li, 2000; Li et al., 1992; Nicholson et al., 2013). Concentrations of potential soil contaminants such as heavy metals and persistent organic compounds vary widely depending on the source of the residue. Hence, estimates of leaching from these residues contributing to human- or eco-toxicity burdens requires data from residue analysis. Such impacts are localized whereas LCA takes a regional approach. Furthermore, data availability is often limited which means contaminants may remain outside the LCA system boundary.

Table 1. Key processes and factors to consider when undertaking a life cycle assessment of residue use as a bio-fertilizer.

\begin{tabular}{|c|c|c|}
\hline Stage & Key processes and factors & Data sources \\
\hline $\begin{array}{l}\text { Residue collection and } \\
\text { transport }\end{array}$ & $\begin{array}{l}\text { - Separated waste collection } \\
\text { - Transport type \& distance }\end{array}$ & $\begin{array}{l}\text { - LCA databases (e.g., } \\
\text { Ecoinvent) } \\
\text { - Measurement data }\end{array}$ \\
\hline $\begin{array}{l}\text { Residue treatment } \\
\text { (composting) }\end{array}$ & $\begin{array}{l}\text { - Fuel use of machinery operations } \\
\text { - Emissions to air }\left(\mathrm{NH}_{3}, \mathrm{CH}_{4},\right. \\
\text { particulates })\end{array}$ & $\begin{array}{l}\text { - Various LCA databases } \\
\text { and technology-specific } \\
\text { emission factors (e.g., EC, } \\
\text { 2010; Saer et al., 2013) } \\
\text { - Measurement data }\end{array}$ \\
\hline $\begin{array}{l}\text { Residue treatment } \\
\text { (anaerobic digestion) }\end{array}$ & $\begin{array}{l}\text { - Biogas leakage }\left(\mathrm{CH}_{4}\right) \\
\text { - Digestate storage }\left(\mathrm{CH}_{4}, \mathrm{NH}_{3}\right) \\
\text { - Fossil energy replacement }\end{array}$ & $\begin{array}{l}\text { - Various LCA databases } \\
\text { and technology-specific } \\
\text { emission factors (e.g., } \\
\text { Jungbluth et al., 2007; } \\
\text { Misselbrook et al., 2012; } \\
\text { Rodhe et al., 2015) } \\
\text { - Measurement data }\end{array}$ \\
\hline \multirow[t]{2}{*}{ Field application } & Tractor operations & Various LCA databases \\
\hline & $\begin{array}{l}\text { - Direct emissions to air }\left(\mathrm{NH}_{3} \text {, }\right. \\
\left.\mathrm{N}_{2} \mathrm{O}\right) \\
\text { - Nutrient losses to water } \\
\text { - Indirect emissions to air }\left(\mathrm{N}_{2} \mathrm{O}\right)\end{array}$ & $\begin{array}{l}\text { - GHG reporting guidelines } \\
\text { (IPCC, 2006) } \\
\text { - Nutrient cycling or } \\
\text { budgeting models (e.g., Li et } \\
\text { al., 1992; Nicholson et al., } \\
\text { 2013) }\end{array}$ \\
\hline \multirow[t]{2}{*}{ Post field application } & $\begin{array}{l}\text { Contaminant (e.g., heavy metal) } \\
\text { leaching }\end{array}$ & Measurement data \\
\hline & $\begin{array}{l}\text { Fertilizer replacement values } \\
(\text { FRV) }\end{array}$ & $\begin{array}{l}\text { - National fertilizer } \\
\text { recommendations and } \\
\text { models, e.g., } \\
\text { Jordbruksverket (2015) and } \\
\text { Nicholson et al. (2013) }\end{array}$ \\
\hline
\end{tabular}




\begin{tabular}{|l|l|l|}
\hline \multirow{1}{*}{} & & $\begin{array}{l}\text { - Soil type, application } \\
\text { method and local climate } \\
\text { data may be required }\end{array}$ \\
\cline { 2 - 3 } & $\begin{array}{l}\text { Avoided chemical fertilizer } \\
\text { manufacture }\end{array}$ & Various LCA databases \\
& $\begin{array}{l}\text { Avoided chemical fertilizer } \\
\text { application }\end{array}$ & $\begin{array}{l}\text { - GHG reporting guidelines } \\
\text { (IPCC, 2006) }\end{array}$ \\
& & $\begin{array}{l}\text { - Nutrient cycling or } \\
\text { budgeting models (e.g., Li et } \\
\text { al., 1992; Nicholson et al., } \\
\text { 2013) }\end{array}$ \\
\cline { 2 - 3 } & Soil carbon sequestration & $\begin{array}{l}\text { Soil nutrient and carbon } \\
\text { cycling models (e.g., } \\
\text { Björnsson et al. 2013; Li et } \\
\text { al., 1992; Prade et al., 2014) }\end{array}$ \\
\hline $\begin{array}{l}\text { Alternative residue } \\
\text { fate }\end{array}$ & $\begin{array}{l}\text { - Country-specific data } \\
\text { - Various LCA databases }\end{array}$ \\
& - Landfill & $\begin{array}{l}\text { - Waste management LCA } \\
\text { models (e.g., EASETECH: } \\
\text { Clavreul et al., 2014) }\end{array}$ \\
\hline
\end{tabular}

Detailed fertilizer or nutrient budgeting manuals such as Stallgödselkalkylen in Sweden (EC, 2009) and national recommendations for fertilization (Jordbruksverket, 2015) estimate the fertilizer replacement value (FRV) for various organic residues, sometimes in relation to timing and technology of application, soil and crop type. A convenient nutrient budgeting tool, MANNER-NPK (Nicholson et al., 2013), estimates FRV and $\mathrm{NH}_{3}$ and $\mathrm{NO}_{3}$ emissions for a wide range of organic residues depending on their specific composition, and the timing, location, method and prevailing weather conditions during application. This tool was used in the case study presented below (Section 2.1.2).

\subsubsection{LCA case study of decentralized anaerobic digestion and digestate reuse}

\section{Goal and scope definition}

The environmental balance of two viable farm biogas options in Sweden was assessed using an expanded-boundary LCA approach and the LCAD EcoScreen tool described in Styles et al. (2016). The construction and manufacture of buildings and equipment were excluded from the scope, as is typical for bioenergy carbon footprints (EC, 2009). Results were calculated for four environmental impact categories based on CML (2010) characterization factors: global warming potential (GWP) expressed as $\mathrm{CO}_{2} \mathrm{e}$, eutrophication potential (EP) expressed as $\mathrm{PO}_{4} \mathrm{e}$, acidification potential (AP) expressed as $\mathrm{SO}_{2} \mathrm{e}$, and fossil resource depletion potential (FRDP) expressed as MJe. For example, GWP factors for $\mathrm{CH}_{4}$ and $\mathrm{N}_{2} \mathrm{O}$ are 25 and 298, respectively, for a 100-year time-scale. The analysis was performed with a functional unit of both one year of plant operation and one $\mathrm{Mg}$ of dry matter input to the digesters for each of the substrates considered.

The LCAD EcoScreen tool was parameterised as described in Styles et al. (2016) for smallscale anaerobic digestion plants, assuming counterfactual storage of manure and digestate in open tanks and trailing hose application to fields in accordance with crop nutrient requirements. Key parameters were updated based on data specific to Swedish farm-scale biogas plants presented in Ahlberg-Eliasson et al. (2017). 
Two farm biogas typologies were evaluated, based on characteristics of existing farm biogas plants in Sweden described in Ahlberg-Eliasson et al. (2017). The average substrate loading rate and the average biomethane yield reported for three plants digesting pig slurry were used to parameterise a "Pig slurry" (P) scenario (Table 2). In addition, substrate loading and biomethane yields were derived for a "Pig slurry \& organic residues" (PO) scenario based on volatile solid (VS) inputs from major substrate types across nine pig slurry and organic residue plants (Ahlberg-Eliasson et al., 2017) (Table 2).

Table 2. Substrate loading rates and average biomethane yields ( \pm standard error of the mean) per Mg substrate for the two farm biogas plant typologies considered in this study. FM = Fresh matter.

\begin{tabular}{|c|c|c|c|}
\hline Substrate/parameter & Unit & Pig slurry (P) & $\begin{array}{l}\text { Pig slurry \& organic } \\
\text { residues (PO)* }\end{array}$ \\
\hline Pig slurry & \multirow{4}{*}{$\mathrm{Mg} \mathrm{FM} \mathrm{yr}^{-1}$} & 10,052 & 10,927 \\
\hline Food waste & & 0 & 535 \\
\hline Slaughterhouse waste & & 0 & 1,042 \\
\hline Grass silage & & 0 & 185 \\
\hline Biomethane yield & $\mathrm{m}^{3} \mathrm{Mg}^{-1} \mathrm{FM}$ & $10( \pm 3.3$ SEM $)$ & $18( \pm 3.3$ SEM $)$ \\
\hline \multicolumn{4}{|c|}{$\begin{array}{l}* \text { Composition derived from approximate average } \% \text { VS contributions across nine plants of } \\
65 \% \text { pig slurry, } 15 \% \text { food waste, } 15 \% \text { slaughterhouse waste, and } 5 \% \text { grass silage (Ahlberg- } \\
\text { Eliasson et al., 2017). }\end{array}$} \\
\hline
\end{tabular}

Substrate characteristics were taken from Ahlberg-Eliasson et al. (2017) for pig slurry, and from Styles et al. (2016) and FNR (2012) for other organic residues (Table 3).

Table 3. Characteristics of the substrates considered. FM = Fresh matter.

\begin{tabular}{|c|c|c|c|c|c|c|c|}
\hline Substrate & $\begin{array}{l}\text { Total } \\
\text { solids }\end{array}$ & $\begin{array}{c}\text { Volatile } \\
\text { solids }\end{array}$ & Norg & $\begin{array}{l}\mathbf{N H}_{4}-\mathbf{N} \\
\mathrm{Mg}^{-1} \mathrm{FN}\end{array}$ & $\mathbf{N}_{\text {tot }}$ & $\mathbf{P}$ & $\mathbf{K}$ \\
\hline Pig slurry & 62 & 49.6 & 1.83 & 2.63 & 4.47 & 0.77 & 2.0 \\
\hline Food waste & 260 & 234 & 1.40 & 5.62 & 7.02 & 0.57 & 2.74 \\
\hline $\begin{array}{l}\text { Slaughterhouse } \\
\text { waste }\end{array}$ & 150 & 120 & 1.25 & 1.81 & 3.06 & 1.53 & 1.57 \\
\hline Grass silage & 250 & 225 & 3.39 & 1.99 & 5.38 & 0.87 & 5.19 \\
\hline
\end{tabular}

It was assumed that food waste and slaughterhouse waste were transported $25 \mathrm{~km}$ to the biogas plant, and would have been sent to incineration with energy recovery in the counterfactual, whilst grass silage was transported $5 \mathrm{~km}$ to be applied to fields, with tractor-trailer transport emission factors taken from Ecoinvent v3.0 (Weidema et al., 2013). Field emissions were calculated using residue-specific FRV and emissions calculated using the MANNER-NPK tool assuming application rate of $100 \mathrm{~kg}$ total $\mathrm{N}$ per hectare to a sandy-clay-loam arable soil in Spring (March $15^{\text {th }}$ ). To account for long-term mineralization of organic $\mathrm{N}$, which can contribute over $30 \mathrm{~kg} \mathrm{~N} \mathrm{ha}^{-1} \mathrm{yr}^{-1}$ (Defra, 2010), it was assumed that $25 \%$ of the residual organic $\mathrm{N}$ becomes available for plant uptake. The IPCC (2006) default $\mathrm{NO}_{3}-\mathrm{N}$ leaching rate of $30 \%$ of applied $\mathrm{N}$ was used to reflect the comparatively high leaching loss of $\mathrm{N}$ mineralized from organic residues, which does not become available in synchrony with plant demand. Avoided 
chemical fertilizer manufacture and avoided fertilizer application emissions were accounted for using fixed field $\mathrm{NO}_{3}-\mathrm{N}$ and $\mathrm{NH}_{3}-\mathrm{N}$ emission factors of 0.1 (Styles et al., 2015) and 0.02 (Misselbrook et al., 2012), respectively. The fertilizer types replaced by plant-available N, P and $\mathrm{K}$ were ammonium nitrate, triple superphosphate and potassium chloride, respectively.

To explore the possible magnitude of any SOC accumulation effect associated with RBF application to land, it was assumed that $13 \%$ of the carbon contained in digested residues remained sequestered in the soil as long-term SOC, assuming a total solids carbon ratio of 0.38 (Bruun et al., 2006). Table 4 summarizes the methods applied to derived inventory data for the LCA within the LCAD EcoScreen tool (Styles et al., 2016).

Table 4. Methods applied to calculate activity data, emissions and environmental burdens in relation to a reference flow of one $\mathrm{Mg}$ feedstock dry matter, derived from Styles et al. (2016).

\begin{tabular}{|c|c|c|}
\hline Process & & $\begin{array}{l}\text { Method to calculate primary emissions and burdens in relation to } \\
\text { feedstock inputs }\end{array}$ \\
\hline \multirow[t]{7}{*}{$\begin{array}{l}\text { Incurred } \\
\text { processes }\end{array}$} & $\begin{array}{l}\text { Grass } \\
\text { cultivation }\end{array}$ & $\begin{array}{l}\text { Burdens }=\mathrm{Mg} \text { DM } \times \text { grass cultivation burdens assuming mineral } \\
\text { fertilizer application (Styles et al., 2015b) x } 1.11 \text { ( } 10 \% \text { silage loss). }\end{array}$ \\
\hline & Transport & $\begin{array}{l}\text { Burdens = Mg DM / DM \% of wet weight (Table } 3 \text { ) x } 5 \mathrm{~km} / 50 \mathrm{~km} \\
\text { for crops/wastes x Ecoinvent v3.1 burdens per tkm for tractor- } \\
\text { trailer/16-32 tonne truck (Table } 3 \text { ). }\end{array}$ \\
\hline & $\begin{array}{l}\text { Digester } \\
\text { leakage }\end{array}$ & $\begin{array}{l}\left.\mathrm{kg} \mathrm{CH} \mathrm{CH}_{4}=\mathrm{Mg} \mathrm{DM} \times \mathrm{m}^{3} / \mathrm{Mg} \mathrm{CH}_{4} \text { yield (Table } 2\right) \times 0.67 \mathrm{~kg} / \mathrm{m}^{3} \times 1 \% \\
\text { digester loss (Adams et al., 2015). }\end{array}$ \\
\hline & $\begin{array}{l}\text { CHP } \\
\text { combustion }\end{array}$ & $\begin{array}{l}\left.\mathrm{kg} \mathrm{CH} \mathrm{CH}_{4}=\mathrm{Mg} \mathrm{DM} \mathrm{x} \mathrm{m} / \mathrm{Mg} \mathrm{CH}_{4} \text { yield (Table } 2\right) \times 0.67 \mathrm{~kg} / \mathrm{m}^{3}-1 \% \\
\text { digester loss } \times 0.5 \% \mathrm{CHP} \text { slip. } \\
\text { AP and EP burdens }=\mathrm{MJ} \mathrm{CH}_{4} \times \text { natural gas CHP burdens from } \\
\text { Ecoinvent v3.1. }\end{array}$ \\
\hline & $\begin{array}{l}\text { Digestate } \\
\text { storage }\end{array}$ & 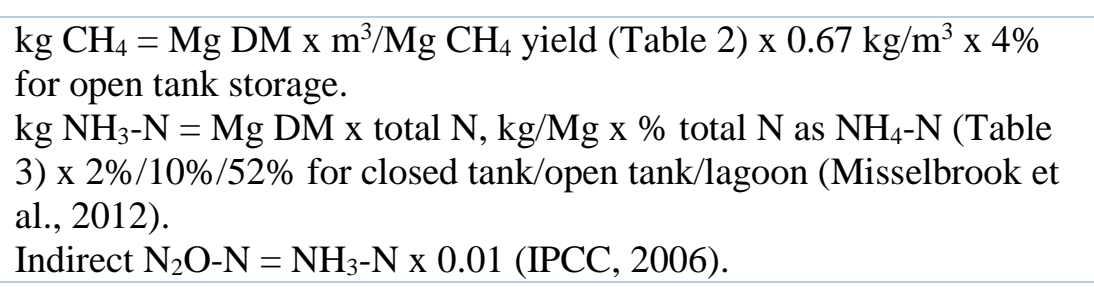 \\
\hline & $\begin{array}{l}\text { Digestate } \\
\text { transport }\end{array}$ & $\begin{array}{l}\text { Burdens = Mg DM / DM \% of wet weight (Table } 3) \times 5 \mathrm{~km} \text { ( } 0 \text { for } \\
\text { manure digestate }- \text { transported anyway) x burdens per tkm for } \\
\text { tractor-trailer from Ecoinvent v3.1. Assumes } 1 \mathrm{Mg} \text { digestate per } 1 \\
\text { Mg feedstock wet weight. }\end{array}$ \\
\hline & $\begin{array}{l}\text { Digestate } \\
\text { application }\end{array}$ & 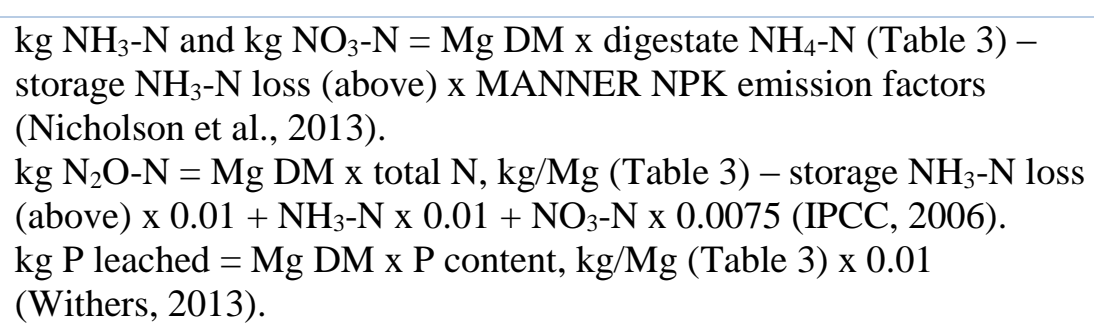 \\
\hline
\end{tabular}




\begin{tabular}{|c|c|c|}
\hline & & $\begin{array}{l}\text { Fertiliser replacement credits }=\mathrm{Mg} \mathrm{DM} \times \text { nutrient contents, } \mathrm{kg} / \mathrm{Mg} \\
\left(\text { Table } 3 \text { ) - storage } \mathrm{NH}_{3}-\mathrm{N} \text { loss (above) x MANNER NPK }\right. \\
\text { availability factors (Nicholson et al., 2013) x fertilizer manufacture } \\
\text { and application credits (described below). } \\
\text { Soil C sequestration }=\mathrm{Mg} \text { DM digestate } \times 0.38 \mathrm{C} \text { ratio x } 0.13 \text { long- } \\
\text { term sequestration ratio (Bruun et al., 2006). }\end{array}$ \\
\hline \multirow[t]{7}{*}{$\begin{array}{l}\text { Avoided } \\
\text { processes } \\
\text { (credits) }\end{array}$} & $\begin{array}{l}\text { Avoided } \\
\text { manure } \\
\text { storage }\end{array}$ & $\begin{array}{l}\text { Avoided } \mathrm{kg} \mathrm{CH} \mathrm{CH}_{4}=\mathrm{Mg} \text { DM x } 800 \mathrm{~kg} / \mathrm{Mg} \text { volatile solids } \times \mathrm{CH}_{4-} \\
\text { producing capacity for manure type (IPCC, 2006) x } 0.67 \mathrm{~kg} / \mathrm{m}^{3} \mathrm{CH}_{4} \text { x } \\
\mathrm{CH}_{4} \text { conversion factor by system type (IPCC, 2006). } \\
\text { Avoided } \mathrm{kg} \mathrm{N} \mathrm{N}_{2} \mathrm{O}-\mathrm{N}=\mathrm{Mg} \text { DM x total N, } \mathrm{kg} / \mathrm{Mg}(\text { Table } 3) \times \text { storage } \\
\text { system emission factors (IPCC, 2006). } \\
\left.\text { Avoided } \mathrm{kg} \mathrm{NH} \mathrm{NH}_{3} \mathrm{~N}=\mathrm{Mg} \text { DM x total } \mathrm{N}, \mathrm{kg} / \mathrm{Mg} \text { (Table } 3\right) \times \% \text { total } \mathrm{N} \\
\text { as } \mathrm{NH}_{4}-\mathrm{N} \text { (Webb and Misselbrook, 2004) x storage system emission } \\
\text { factors (Misselbrook et al., 2012). }\end{array}$ \\
\hline & $\begin{array}{l}\text { Avoided } \\
\text { manure } \\
\text { application }\end{array}$ & 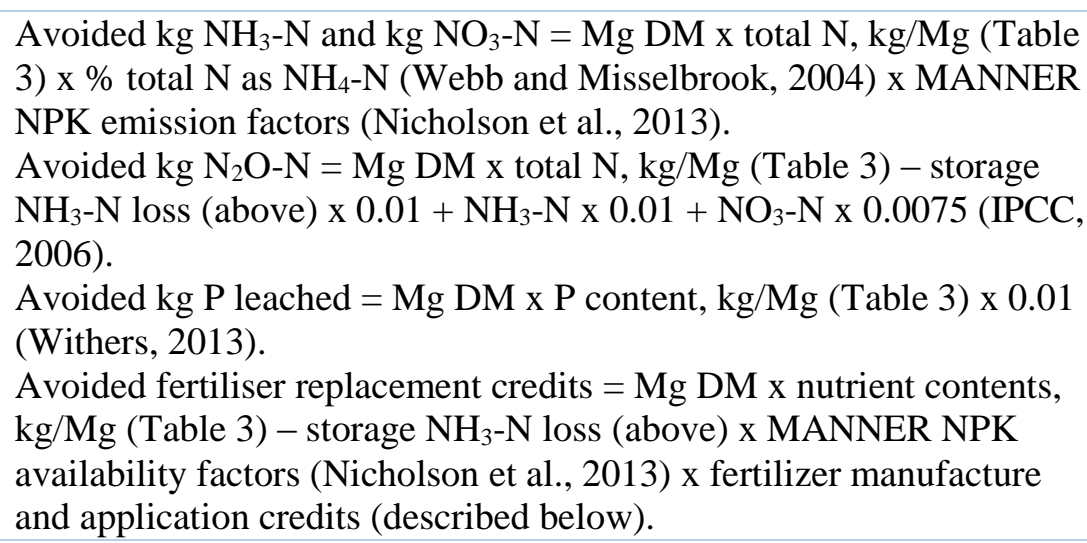 \\
\hline & $\begin{array}{l}\text { Avoided } \\
\text { field residue } \\
\text { decompositi } \\
\text { on }\end{array}$ & $\begin{array}{l}\text { Avoided emissions, soil C sequestration and fertilizer replacement } \\
\text { credits. Net credit values in Table } 3 .\end{array}$ \\
\hline & $\begin{array}{l}\text { Avoided } \\
\text { incineration } \\
\text { with energy } \\
\text { recovery }\end{array}$ & $\begin{array}{l}\text { Avoided burdens = } 1 \mathrm{Mg} \text { DM animal processing or food waste } \mathrm{x} \\
\text { Ecoinvent v3.1 burdens for incineration, corrected for moisture } \\
\text { content - credits for avoided natural gas electricity generation. }\end{array}$ \\
\hline & $\begin{array}{l}\text { Avoided } \\
\text { marginal } \\
\text { grid } \\
\text { electricity } \\
\text { generation }\end{array}$ & $\begin{array}{l}\text { Avoided burdens }=\mathrm{Mg} \mathrm{DM} \mathrm{x} \mathrm{m} 3 / \mathrm{Mg} \mathrm{CH}_{4} \text { yield (Table 3) x } 0.67 \\
\mathrm{~kg} / \mathrm{m}^{3}-1 \% \text { digester loss }-0.5 \% \text { CHP slip x } 50 \mathrm{MJ} / \mathrm{kg} \text { LHV x CHP } \\
\text { electricity efficiency ( } 35 \%)-6 \% \text { parasitic load x natural gas } \\
\text { combined cycle electricity generation burdens per MJ generated from } \\
\text { Ecoinvent v3.1. }\end{array}$ \\
\hline & $\begin{array}{l}\text { Avoided } \\
\text { oil/gas } \\
\text { heating }\end{array}$ & $\begin{array}{l}\left.\text { Avoided burdens }=\mathrm{Mg} \mathrm{DM} \mathrm{x} \mathrm{m} 3 / \mathrm{Mg} \mathrm{CH}_{4} \text { yield (Table } 3\right) \times 0.67 \\
\mathrm{~kg} / \mathrm{m}^{3}-1 \% \text { digester loss }-0.5 \% \text { CHP slip x } 50 \mathrm{MJ} / \mathrm{kg} \mathrm{LHV} \times 50 \% \\
\text { CHP heat efficiency x } 50 \% \text { utilization rate x oil } / \mathrm{gas} \text { heat burdens per } \\
\text { MJ heat from Ecoinvent v3.1. }\end{array}$ \\
\hline & $\begin{array}{l}\text { Avoided } \\
\text { NPK } \\
\text { fertiliser } \\
\text { manufacture }\end{array}$ & $\begin{array}{l}\text { Avoided burdens }=\mathrm{Mg} \text { DM x nutrient contents, } \mathrm{kg} / \mathrm{Mg} \text { (Table } 3 \text { ) - } \\
\text { storage } \mathrm{NH}_{3}-\mathrm{N} \text { loss (above) x MANNER NPK availability factors } \\
\text { (Nicholson et al., 2013) x Ecoinvent v3.1 burdens for ammonium- }\end{array}$ \\
\hline
\end{tabular}




\begin{tabular}{|c|c|}
\hline & $\begin{array}{l}\text { nitrate, triple superphosphate and potassium chloride expressed per } \\
\mathrm{kg} \mathrm{N}, \mathrm{P} \text { and } \mathrm{K} \text {. }\end{array}$ \\
\hline $\begin{array}{l}\text { Avoided } \\
\text { NPK } \\
\text { fertiliser } \\
\text { application }\end{array}$ & $\begin{array}{l}\text { Avoided } \mathrm{kg} \mathrm{NH}_{3}-\mathrm{N}=\text { avoided fertilizer } \mathrm{N} \text { application (above) x } 0.017 \\
\text { (Misselbrook et al., 2012). } \\
\text { Avoided kg N leached }=\text { avoided fertilizer N application (above) x } \\
0.10 \text { (Duffy et al., 2013). } \\
\text { Avoided kg N2 } \mathrm{O}-\mathrm{N}=\text { avoided fertilizer } \mathrm{N} \text { application (above) x } 0.01 \\
+\mathrm{NH}_{3}-\mathrm{N} \text { x } 0.01+\mathrm{NO}_{3}-\mathrm{N} \text { x } 0.0075 \text { (IPCC, 2006). } \\
\text { Avoided kg P leached = avoided fertilizer P application (above) x } \\
0.01 \text { (Withers, 2013). }\end{array}$ \\
\hline
\end{tabular}

\subsection{Economic dimension}

To assess the techno-economics of handling digestate at the farm level, an economic model was used to determine the net present value (NPV) (Brundin and Rodhe, 1994; Rodhe et al., 2006). The NPV of an investment is determined by calculating the present value of the total benefits and costs by discounting the future value of each cash flow. NPV is used to assess whether a change in farm management will result in a net profit or loss. The model describes the handling system and the relationships between soil, crop, technology and the organization that influences the profitability of different systems for handling digestate on farms. The revenues are calculated as the sum of nutrients $(\mathrm{N}, \mathrm{P}$ and $\mathrm{K}$ ) available to plants. Costs are included for machinery (spreaders), labour and soil compaction. The costs could be divided into variable costs (depends mainly on spreading strategy) and fixed costs (annuity costs for the investment). Costs were subtracted from revenues to give the net present value (Euro $\mathrm{Mg}^{-1} \mathrm{yr}^{-1}$ ).

The economics were calculated for handling of raw liquid digestate $(2.5 \%$ dry matter $)$ and concentrated solid digestate $(25 \%$ dry matter) at farm level in Southern Sweden. Average nutrient contents of the liquid digestate in the region were estimated at $4.8 \mathrm{~kg}$ total- $\mathrm{N} \mathrm{Mg}^{-1}, 3.6$ $\mathrm{kg}$ total ammoniacal $\mathrm{N}$ (TAN) $\mathrm{Mg}^{-1}, 0.4 \mathrm{~kg} \mathrm{P} \mathrm{Mg}^{-1}$, and $4.2 \mathrm{~kg} \mathrm{~K} \mathrm{Mg}^{-1}$ on a fresh matter basis. For solid digestate the estimated contents were $10.9 \mathrm{~kg}$ total- $\mathrm{N} \mathrm{Mg}^{-1}, 3.2 \mathrm{~kg}$ TAN Mg${ }^{-1}, 2.9 \mathrm{~kg}$ $\mathrm{P} \mathrm{Mg}^{-1}$, and $3.8 \mathrm{~kg} \mathrm{~K} \mathrm{Mg}^{-1}$. Simulations were also performed with concentrations of $+25 \%$ and $-25 \%$ of the estimated concentrations. The calculations were done with set conditions prevailing in the region and on the farms concerning crop rotation and soil texture (Rodhe et al., 2006). Different spreading strategies $\left(2 / 3^{\text {rd }}\right.$ of the product spread in summer for growing winter wheat or $2 / 3^{\text {rd }}$ spread before sowing in autumn), application rates $\left(20\right.$ or $\left.30 \mathrm{Mg} \mathrm{ha}^{-1}\right)$ and application times (early summer or autumn) were calculated for, on top of the different properties of the residues (low, average or high nutrient content). For the liquid digestate, trailing hose application was assumed, while the solid digestate was spread using a conventional solid manure spreader. For the prevailing conditions, storage cost was not included, as the farm companies did not finance it, nor was the cost for the digestate included as it was freely available.

In addition to the above NPV calculations for digestate handling at the farm level, an estimation of farm-scale biogas plant construction and operating costs, as well as revenues from heat and electricity generation, and possible gate fees for food and slaughterhouse waste, has been performed using the NNFCC AD cost calculator (NNFCC, 2013) adapted to Southern Sweden. These data were used to calculate the internal rate of return (IRR), i.e., the discount rate that makes the overall NPV equal to 0 . A $6 \%$ interest rate was applied throughout the economic modelling where amortisation calculations were required, e.g., for AD capital investment costs. Farm AD unit capital investment costs were calculated at a fixed cost of $€ 602 \mathrm{~m}^{-3}$ digester capacity (capacities calculated according to feedstock mixes using NNFCC model). Fixed 
proportions of capital expenditure were allocated to buildings and machinery, with depreciation lifetimes of 20 and 10 years, respectively. Capital investments were converted into annual capital repayments based on loan repayment over building/machinery lifetimes plus accrued interest at a rate of $6 \%$. Operating and maintenance $(\mathrm{O} \& \mathrm{M})$ costs were taken from NNFCC model estimations. AD income from electricity export to grid was valued at $€ 0.057 \mathrm{kWh}^{-1}$. Avoided electricity import was valued at $€ 0.17 \mathrm{kWh}^{-1}$. Avoided heating oil is costed at $€$ $0.08 / \mathrm{kWh}(€ 0.80 / \mathrm{L})$ including all taxes and delivery in Sweden.

\subsection{Social dimension: Stakeholder perception study}

An important prerequisite for biogas production is marketing of biofertilizer. In order to secure future utilization of biofertilizer, it is necessary to understand what drives stakeholders to utilize the product. To investigate societal acceptance on future utilization of biofertilizer, a questionnaire on stakeholder perception of the recovered bio-fertilizers was performed in relation to a planned biogas plant in Southern Sweden. It concerns an interview study among the eight key stakeholder groups in Southern Sweden. The aim was to map priorities and the development of biofertilizer policies for different stakeholders who could be affected by biogas production in the area. The stakeholders were chosen in collaboration with the waste and biogas company Sysav, located in Scania, Sweden. They include the Swedish Farmers' Organization, the Swedish Organic Farmers Organization KRAV, the Organization for Food Certification Standards (Sigill), Nordic Sugar, the Swedish Farmers Association, the Swedish Waste Management and Recycling Association (Avfall Sverige), the County Administration Board for Scania, and Malmö City Environmental Department. The organization Swedish Milk was also interviewed, but did not have a policy for biofertilizer in place at the time of this study. For each stakeholder group, the head of the institution was interviewed in person, following an internal discussion on pre-prepared questions (see Annexe 1) within the respective institution. The results of the inquiry are hence representative for the entire institution.

\section{Results and Discussion}

\subsection{Environmental dimension: Life cycle assessment (LCA)}

Table 5 summarizes the environmental balance of the two considered farm biogas plant typologies across the four most important environmental impact categories. Digestion of pig slurry leads to a considerable reduction in GHG emissions, avoiding almost $858 \mathrm{Mg} \mathrm{CO}_{2} \mathrm{e}$ per year, and saves over 3,317 GJe of fossil energy - the latter value being somewhat sensitive to biomethane yields (Table 5). The largest GHG credit arises from the avoidance of conventional manure management (slurry storage and spreading) (Figure 2). Eutrophication and acidification burdens slightly increase (Table 5), largely owing to ammonia emissions from digestate storage and application being greater than counterfactual emissions from undigested pig slurry storage and application (Figure 2). Indeed, through anaerobic digestion the ratio of ammonium nitrogen relative to total nitrogen increases, thereby increasing the potential amount of ammoniac volatilization (Vaneeckhaute et al., 2013b). More appropriate digestate storage and application strategies, e.g., storage of digestate in covered tanks and application through injection, could further improve the overall environmental balance. Finally, the fossil resource depletion potential is significantly reduced through farm-scale digestion, mainly due to the avoided use of fossil energy through biogas production and utilisation (Figure 2).

Table 5. Summary of the environmental balance results for the two farm biogas plant typologies considered ( $\pm \%$ based on standard error around biomethane yields).

\begin{tabular}{|c|c|c|c|c|}
\hline Scenario & Global warming & Eutrophication & Acidification & $\begin{array}{c}\text { Fossil resource } \\
\text { depletion }\end{array}$ \\
\hline
\end{tabular}




\begin{tabular}{|c|c|c|c|c|}
\hline & $\mathrm{kg} \mathrm{CO}_{2} \mathrm{e} \mathrm{yr}^{-1}$ & $\mathrm{~kg} \mathrm{PO}_{4} \mathrm{e} \mathrm{yr}^{-1}$ & 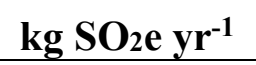 & MJe $\mathbf{y r}^{-1}$ \\
\hline Pig slurry (P) & $-857,523( \pm 4 \%)$ & $1,021( \pm 0.1 \%)$ & $3,224( \pm 0.5)$ & $\begin{array}{c}-3,317,305 \\
( \pm 30 \%)\end{array}$ \\
\hline $\begin{array}{c}\text { Pig slurry }+ \\
\text { organic residues } \\
\text { (PO) }\end{array}$ & $-998,503( \pm 3 \%)$ & $1,737( \pm 0.1 \%)$ & $5,988( \pm 0.3 \%)$ & $\begin{array}{c}-6,029,832 \\
( \pm 17 \%)\end{array}$ \\
\hline
\end{tabular}

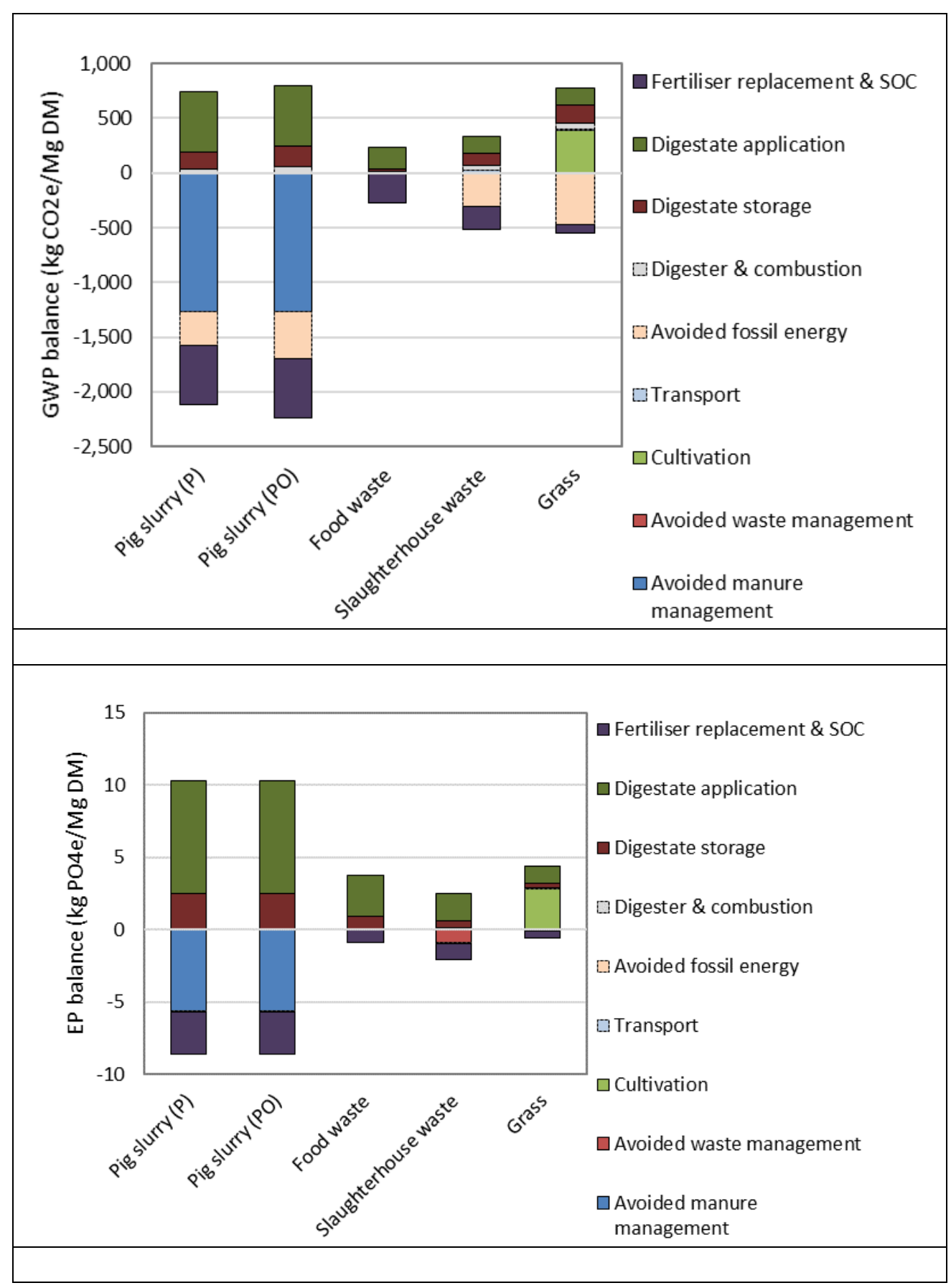




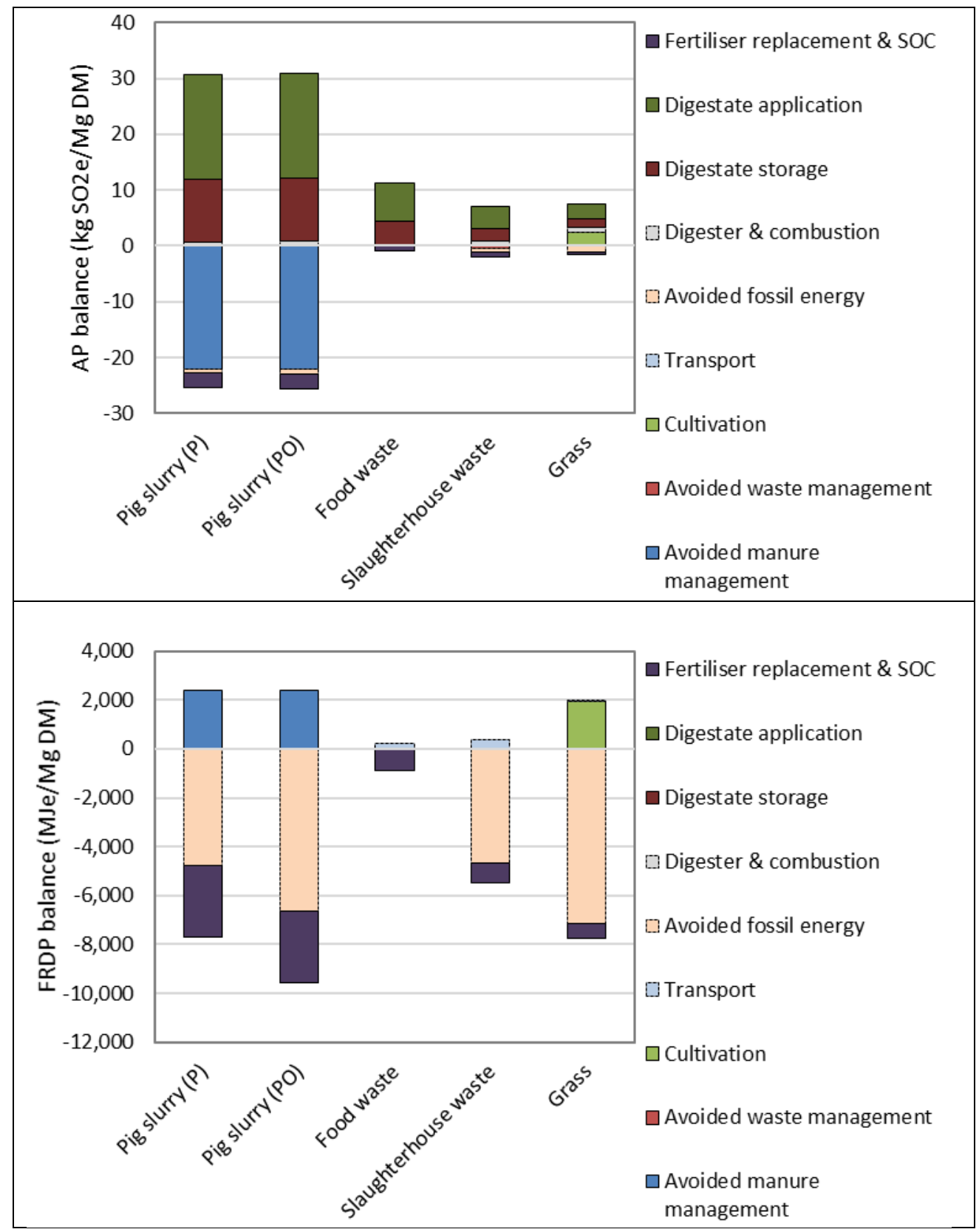

Figure 2. Environmental balance per $\mathrm{Mg}$ dry matter for each substrate, for (top to bottom) global warming potential (GWP), eutrophication potential (EP), acidification potential (AP) and resource depletion potential (RDP). $\mathrm{P}=$ pig slurry scenario; $\mathrm{PO}=$ Pig slurry $\&$ organic residues scenario. Processes not directly related to nutrient recycling are indicated with dotted borders.

\subsection{Economic dimension: NPV and IRR calculations}

The net present value (NPV) for the liquid digestate handled using the model described in Brundin and Rodhe (1994) and Rodhe et al. (2006) was between $€-0.48$ and $€ 1.98 \mathrm{Mg}^{-1} \mathrm{yr}^{-1}$. The main impacting factors were nutrient content, spreading strategy, application rate and time. A $25 \%$ increase in nutrient concentrations of N, P and $\mathrm{K}$ meant an increased value of the liquid digestate by $€ 0.85-1.02 \mathrm{Mg}^{-1} \mathrm{yr}^{-1}$. A higher application rate of the liquid digestate in growing crops (30 Mg ha ${ }^{-1}$ compared to $20 \mathrm{Mg} \mathrm{ha}^{-1}$ ) improved the profitability for each spreading strategy with about $€ 0.20-0.60 \mathrm{Mg}^{-1} \mathrm{yr}^{-1}$. At a rate of $30 \mathrm{Mg} \mathrm{ha}^{-1}$, it was also more profitable 
to spread the main part $(2 / 3)$ of liquid digestate in the fore season for growing crops than spreading the main part before sowing in autumn. At a lower rate of $20 \mathrm{Mg} \mathrm{ha}^{-1}$, it was more profitable to apply most of the digestate before sowing in autumn due to the lower soil compaction of autumn spreading compared to spreading in spring.

The average NPV for solid digestate handled was about $€ 4.55 \mathrm{Mg}^{-1} \mathrm{yr}^{-1}$. This higher value compared to liquid digestate can be explained by the higher $\mathrm{N}$ and $\mathrm{P}$ concentration, the possibility for autumn spreading with relatively low soil compaction, and the lower investment costs for the spreader as compared to a slurry spreader. As expected, an operational strategy of the biogas plant that results in a digestate with higher nutrient concentration improves the value of the digestate. This can, for example, be achieved through optimization of the co-digestion mixture or through solid-liquid separation following digestion.

When also including estimations of farm-scale biogas plant construction and operating costs, as well as revenues from heat and electricity generation and possibly from gate fees for food and slaughterhouse waste, the internal rate of return (IRR) after 20 years is about $5.1 \%$ for the $\mathrm{P}$ scenario and $23.6 \%$ for the PO scenario described in Table 2. A breakdown between profit and loss is provided in Table 6 as calculated using the NNFCC AD calculator (NNFCC, 2013). Costs for the PO scenario increase with a factor 1.3 as compared to the $\mathrm{P}$ scenario due to the use of an energy feedstock (grass silage). Nevertheless, revenues are almost tripled due to the higher biogas production of the organic waste feedstock as compared to pig manure, on top of the considered gate fees for food waste and slaughterhouse waste. As observed in other studies (e.g., Jhong-Hwa et al., 2006, Ossiansson and Lidholm, 2008), it can be stated that monodigestion of pig manure is not feasible from an economic point of view due to the low biogas potential of the feedstock. However, decentralized co-digestion of animal manure with organic wastes seems viable based on the results. Additional governmental support for small-scale AD plants should be provided to leverage the GHG and nutrient cycling benefits. For example, when considering a revenue of $€ 15$ per ton of saved $\mathrm{CO}_{2} \mathrm{e}$ emissions, the yearly income for the $\mathrm{P}$ and the PO scenario would increase with $\mathrm{k} € 12.9$ and $\mathrm{k} € 15.0$, respectively, resulting in an IRR of $7.5 \%$ and $25.5 \%$, respectively.

Table 6. Breakdown between profit and loss (euro) for the P (pig manure) and the PO (pig manure + organic residues) scenario calculated using the NNFCC AD calculator (NNFCC, 2013).

\begin{tabular}{|l|c|c|}
\hline Profit and Loss & P (k€) & PO (k€)) \\
This is the P\&L with 50\% Finance repaid & & \\
\hline Income & 45.4 & 143 \\
Electricity & 16.0 & 50.6 \\
Heat & 24.7 & 33.6 \\
Fertiliser Value & 0 & 17.9 \\
Gate Fees & 86.1 & 245 \\
Total Income & & \\
Costs & 0 & 5.25 \\
Energy Feedstock & 49.1 & 62.1 \\
Power inc Capital Repayment & 0 & 0 \\
General overheads & 0 & 0 \\
Land, building & &
\end{tabular}




\begin{tabular}{|l|c|c|} 
Interest Payment & 18.1 & 21.1 \\
Total Costs & 67.2 & 88.5 \\
Profit/Loss & 19.0 & 156 \\
\hline
\end{tabular}

\subsection{Social dimension: Stakeholder perception study}

The interviews showed that 4 out of the 8 stakeholder groups had a policy in place regarding biofertilizers, among which one organization, the Swedish Organic Farmers Organization KRAV, had criteria for the use of biofertilizers within the certification for organic farming (Gunnarsson, 2012). All 8 stakeholder groups predicted a bright future for biofertilizers, but quality assurance and technological developments to concentrate mineral nutrients in the biofertilizers were expected to be crucial to enable biofertilizers to compete with traditional mineral nutrients, synthetically manufactured. The transport distance from the biogas plant to the agricultural fields where the products can be applied, was also pointed out as a crucial point of attention (Gunnarsson, 2012).

All stakeholders were positive to using biofertilizers, with 3 out of the 8 stakeholder groups stating that it was under the condition that the biofertilizer was certified. A certification is in place, which was developed by the Swedish Technological Research Institute in 1996-1999 (Sveriges Tekniska Forskningsinstitut, 2010). 7 out of the 8 stakeholder groups mentioned that the use of biofertilizers returns nutrients to agricultural fields and this was seen as positive. There were, however, very different opinions on whose responsibility it is to return nutrients to the soil, ranging from trade organizations, biogas producers, society or the government.

It was important for all stakeholders to know the origin of the substrates of the biofertilizer, apart from one stakeholder organization who concluded that substrates were approved as long as they were not in excess of the limits set for heavy metals. 4 out of the 8 stakeholder groups expressed awareness of risks for soil contamination with pathogens and heavy metals, and this was pointed out as a key issue in order to guarantee safe products to their customers.

2 out of the 8 stakeholder groups replied that it was important to specify on which crop the biofertilizer can be deposited. All stakeholders, however, regarded biofertilizers as a valuable product rather than a waste residue.

\subsection{Research limitations and recommendations}

From the expanded boundary LCA analysis performed in this study, it is clear that digestate storage and application, fertilizer replacement and soil organic carbon effects, as well as effects related to the avoided manure management (storage + application), are the most important factors influencing the overall environmental balance. Future LCA studies on recycling of biofertilizers should therefore attempt to account for these factors in an accurate way. The LCA framework presented in this study provides guidance for future studies to be more comparable and compatible. Residue-specific data on humification coefficients to accurately represent soil organic carbon effects are lacking and need to be investigated in more detail. Upon implementation of farm-scale anaerobic digestion, attention should be given to appropriate storage and application strategies for the respective digestate in order to minimize nutrient emissions. 
Overall, an important issue for performing a multi-dimensional sustainability assessment is the wide variation of data, such as feedstock characteristics and environmental conditions, over space and time. Therefore, research on the development of a spatiotemporal and multidimensional decision-support simulation tool, including a geographical information system coupled to advanced dynamic mathematical process models, for holistic optimization of organic waste valorization chains is currently ongoing (Vaneeckhaute et al., 2017).

Finally, although this paper shows that the environmental and economic impacts, as well as the social perception of digestate recycling in agricultural regions is favourable, harmonization of the European Fertilizer Regulation (currently under revision so as the facilitate the marketing and application of digestates) with other regulations, such as the European chemical regulation (REACH, 2007), the Animal By-Products Directive (EC, 2002), the Nitrates Directive (EC, 1991) and the Waste Framework Directive (EC, 2008) will be required before effective marketing and use of bio-based fertilizers in the European Union will be possible.

\section{Conclusions}

- The overall environmental balance of farm-scale anaerobic digestion in Southern Sweden is favorable. Digestate storage and application strategies, fertilizer replacement and soil organic carbon effects, as well as counterfactual effects from the avoided conventional manure management are important factors that should be accounted for in future LCA studies.

- The net present value of digestate handling at farm-scale can be positive. The main impacting factors are digestate nutrient content, spreading strategy, application rate and time.

- The internal rate of return of decentralized $\mathrm{AD}$ and digestate handling after 20 years is about $5.1 \%$ for mono-digestion of pig manure and $23.6 \%$ for co-digestion of pig manure with local organic residues in Southern Sweden. Additional governmental support for smallscale AD plants should be provided to leverage the GHG and nutrient cycling benefits.

- Stakeholder perception on the use of recycled products in agriculture is positive for the case of Southern Sweden. A key issue for all stakeholders is quality assurance.

\section{Acknowledgements}

The first author is funded by the Natural Science and Engineering Research Council of Canada (NSERC) through the award of an NSERC Discovery Grant (RGPIN-2017-04838).

\section{References}

ADAS, SAC, 2007. Baseline projections for agriculture and implications for emissions to air and water. ADAS research report for the Department for Environment, Food and Rural Affairs (Defra), UK Government.

Ahlberg-Eliassen, K., Nadeau, E., Levén, L., Schnürer, A., 2017. Production efficiency of Swedish farm-scale biogas plants. Biomass and Bioenergy 97: 27-37.

Björnsson, L., Prade, T., Lantz, M., Börjesson, P., Svensson, S.-E., Eriksson, H., 2013. Impact of biogas crop production on greenhouse gas emissions, soil organic matter and food crop 
production - A case study on farm level, Report No 2013:27, f3, The Swedish Knowledge Centre for Renewable Transportation Fuels and Foundation, Lund, Sweden.

Brundin, S.G., Rodhe, L.K.K., 1994. Comparisons of manure handling systems under Swedish conditions. Journal of Agricultural Engineering Research 58: 181-190.

Bruun, S., Hansen, T.L., Christensen, T.H., Magid, J., Jensen, L.S., 2006. Application of processed organic municipal solid waste on agricultural land - A scenario analysis. Environmental Modeling and Assessment 11: 251-265.

Chiew, Y.L., Spangberg, J., Baky, A., Hansson, P.A., Jonsson, H., 2015. Environmental impact of recycling digested food waste as a fertilizer in agriculture: A case study. Resources, Conservation and Recycling 95: 1-14.

Clavreul, J., Baumeister, H., Christensen, T.H., Damgaard, A., 2014. An environmental assessment system for environmental technologies. Environmental Modelling and Software 60: $18-30$.

CML, 2010. Characterization factors database, Institute of Environmental Sciences (CML), Universiteit Leiden, Leiden, the Netherlands, available from: http://cml.leiden.edu/software/data-cmlia.html

Cordell, D., Drangert, J.O., White, S., 2009. The story of phosphorus: Global food security and food for thought. Global Environmental Change 19: 292-305.

Defra, 2010. Fertiliser Manual RB209, Department for Environment, Food and Rural Affairs, UK Government, available from: http://www.defra.gov.uk/publications/2011/03/25/fertilisermanual-rb209/

EC, 1991. Council Directive 91/676/EEC concerning the protection of waters against pollution caused by nitrates from agricultural sources, European Commission, Brussels, Belgium, December 121991.

EC, 2002. Regulation EC No 1774/2002 of the European Parliament and of the Council laying down Health Rules as regards Animal By-Products not intended for Human Consumption, European Commission, Brussels, Belgium, October 32002.

EC, 2008. Waste Framework Directive 2008/98/EC of the European Parliament and of the Council, European Commission, Brussels, Belgium, November 192008.

EC, 2009. Directive 2009/28/EC of The European Parliament and of The Council of 23 April 2009 on the promotion of the use of energy from renewable sources, Official Journal of the European Union 2009, 16-62, Brussels.

EC, 2010. Commission Staff Working Document Accompanying the Communication from the Commission on future steps in bio-waste management in the European Union [COM(2010) 235 final], European Commission, Brussels, Belgium.

Cong, R.G., Caro, D., Thomsen, M., 2017. Is it beneficial to use biogas in the Danish transport sector? An environmental-economic analysis. Journal of Cleaner Production 165: 1025-1035. 
EUBIA, 2017. Anaerobic Digestion, European Biomass Industry Association, available from:

Eurostat, 2017. Greenhouse gas emission statistics, European Commission, available from: http://ec.europa.eu/eurostat/statisticsexplained/index.php/Greenhouse_gas_emission_statistics

FNR, 2012. Guide to biogas: From production to use, Fachagentur Nachwachsende Rohstoffe (FNR), Gulzow, Germany, available from: https://mediathek.fnr.de/media/downloadable/files/samples/g/u/guide_biogas_engl_2012.pdf

Gunnarsson, I., 2012. Hur säkrar man en framgångsrik avsättning av biogödsel? Avsättning från bord till jord. Bachelor project in Environmental science, Lund University, Lund, Sweden.

IPCC, 2006. IPCC Guidelines for National Greenhouse Gas Inventories, Institute for Global Environmental Strategies (IGES), Hayama, Japan.

Jhong-Hwa, A., Trong, H.D., Sang, D.K., Seokhwan, H., 2006. The effect of calcium on the anaerobic digestion treating swine wastewater. Biochemical Engineering Journal 30: 33-38.

Johnes, P., Moss, B., Phillips, G., 1996. The determination of total nitrogen and total phosphorus concentrations in freshwaters from land use, stock headage and population data: Testing of a model for use in conservation and water quality management. Freshwater Biology 36: $451-473$.

Jordbruksverket, 2015. Yearbook of Agricultural Statistics, Swedish Board of Agriculture, available from:

http://www.jordbruksverket.se/download/18.4d857f2814e3cf3eeda2b510/1435577114308/Su mmary+2015.pdf

JRC, 2014. Solid and gaseous bioenergy pathways: Input values and GHG emissions, Report EUR 26696 EN, Joint Research Center (JRC), Swedish Board of Agriculture, Jönköping, Sweden.

Jungbluth, N., Chudacoff, M., Dauriat, A., Dinkel, F., Doka, G., Faist-Emmenegger, M., Gnansounou, E., Kljun, N., Schleiss, K., Spielmann, M., Stettler, C., Sutter, J., 2007. Life cycle inventories of bioenergy, Ecoinvent report No. 17, Swiss Centre for Life Cycle Inventories, Dübendorf, $\mathrm{CH}$.

Li, C., 2000. Modelling trace gas emissions from agricultural ecosystems. Nutrient Cycling in Agroecosystems 58: 259-276.

Li, C., Frolking, S., Frolking, T., 1992. A model of nitrous oxide evolution from soil driven by rainfall events: Model structure and sensitivity. Journal of Geophysical research 97: 9759-9776.

Misselbrook, T.H., Gilhespy, S.L., Cardenas, L.M., 2012. Inventory of ammonia emissions from UK Agriculture 2011, Department of Environment, Food and Rural Affairs (Defra), UK Government, London, UK. 
Nicholson, F.A., Bhogal, A., Chadwick, D., Gill, E., Gooday, R.D., Lord, E., Misselbrook, T., 610 Rollett, A.J., Sagoo, E., Smith, K.A., Thorman, R.E., Williams, J.R., Chambers, B.J., 2013. An 611 enhanced software tool to support better use of manure nutrients: MANNER-NPK. Soil Use

NNFCC, 2013. Anaerobic digestion economic assessment tool, UK National Non-Food Crop Centre (NNFCC), York, UK.

Ossiansson, E., Lidholm, O., 2008. Application, Uncertainty and Sensitivity Analysis of the Anaerobic Digestion Model by Siegrist et al. (2002) on Household Waste Digestion. MSc Thesis, Lund University, Lund, Sweden.

Prade, T., Svensson, S.-E., Björnsson, L., 2014. Introduction of grass-clover crops as biogas feedstock in cereal-dominated crop rotations, Part I: Effects on soil organic carbon and food production. 9th International Conference on LCA of Food, San Francisco, CA, USA.

REACH, 2007. Registration, Evaluation, Authorisation and Restriction of Chemicals, European Commission, Brussels, Belgium.

Rehl, T., Müller, J., 2011. Life cycle assessment of biogas digestate processing technologies. Resources, Conservation and Recycling 56(1): 92-104.

Rodhe, L., Salomon, E., Edström, M., 2006. Handling of digestate on farm level, JTI-report Agriculture \& Industy no. 347, Swedish Institute of Agricultural and Environmental Engineering, Uppsala, Sweden.

Rodhe, L., Ascue, J., Willén, A., Persson, B.V., Nordberg, A., 2015. Greenhouse gas emissions from storage and field application of anaerobically digested and non-digested cattle slurry. Agriculture, Ecosystems \& Environment 199: 358-368.

Saer, A., Lansing, S., Davitt, N.H., Graves, R.E., 2013. Life cycle assessment of a food waste composting system: Environmental impact hotspots. Journal of Cleaner Production 52: 234244.

Styles, D., Mesa Dominguez, E., Dhadwick, D., 2016. Environmental balance of the UK biogas sector: An evaluation by consequential life cycle assessment. Science of the Total Environment: $560-561$.

Styles, D., Gibbons, J., Williams, A.P., Dauber, J., Stichnothe, H., Urban, B., Chadwick, D., Jones, D.L. 2015. Consequential life cycle assessment of biogas, biofuel and biomass energy options within an arable crop rotation. Global Change Biology Bioenergy: 1305-1320.

Vaneeckhaute, C., Ghekiere, G., Michels, E., Vanrolleghem, P., Tack, F.M.G., Meers, E. 2014. Assessing nutrient use efficiency and environmental pressure of macro-nutrients in bio-based mineral fertilizers: A review of recent advances and best practices at field scale. Advances in agronomy 128: 137-180.

Vaneeckhaute, C., Janda, J., Vanrolleghem, P.A., Tack, F.M.G., Meers, E., 2016. Phosphorus efficiency in bio-based fertilizers: A bio-availability and fractionation study. Pedosphere 26(3): 310-325. 
658 Vaneeckhaute, C., Meers, E., Ghekiere, G., Accoe, F., Tack, F.M.G., 2013a. Closing the 659 nutrient cycle by using bio-digestion waste derivatives as synthetic fertilizer substitutes: A field 660 experiment. Biomass and Bioenergy 55: 175-189.

661 Vaneeckhaute, C., Meers, E. Michels, E., Buysse, J., Tack, F.M.G., 2013b. Ecological and 662 economic benefits of the application of bio-based mineral fertilizers in modern agriculture. 663 Biomass and Bioenergy 49: 239-248.

664

665

Vaneeckhaute, C., Rivest, S., Ouedraogo, B., Belia, E., Fortin, F., Mostafavi, M., 2017. 666 Decision-support tool for setting up optimal waste valorization chains in Québec. Workshop on 667 Québec's Resource Recovery Potential, McGill University, Montréal, QC, Canada, available 668 from: https://www.youtube.com/watch?v=v0S_BJeTW7A

670 Vázquez-Rowe, I, Golkowska, K, Lebuf, V, Vaneeckhaute, C, Michels, E, Meers, E, Benetto, 671 E, Koster, D., 2015. Environmental assessment of digestate treatment technologies using LCA 672 673

674 Weidema, B.P., Bauer, C., Hischier, R., Mutel, C., Nemecek, T., Reinhard, J., Vadenbo, C.O., 675 Wernet, G., 2013. The ecoinvent database: Overview and methodology, Data quality guideline 676 for the ecoinvent database version 3, www.ecoinvent.orgWeidema et al., 2013. 